\title{
HEAVY METALS IN A DEGRADED SOIL TREATED WITH SLUDGE FROM WATER TREATMENT PLANT
}

\author{
Sandra Tereza Teixeira; Wanderley José de Melo*; Érica Tomé Silva \\ UNESP/FCAV - Depto. de Tecnologia, Campus de Jaboticabal, Via de Acesso Prof. Paulo Donato Castellane, \\ km 5 - 14884-900 - Jaboticabal, SP - Brasil. \\ *Corresponding author <wjmelo@fcav.unesp.br>
}

\begin{abstract}
The application of water treatment sludge (WTS) to degraded soil is an alternative for both residue disposal and degraded soil reclaim. This study evaluated effects of the application of water treatment sludge to a Typic Hapludox soil degraded by tin mining in the National Forest of Jamari, State of Rondonia, Brazil, on the content of heavy metals. A completely randomized experimental design with five treatments was used: control $(\mathrm{n}=4)$; chemical control, which received only liming $(\mathrm{n}=4)$; and rates $\mathrm{D}_{100}, \mathrm{D}_{150}$ and $\mathrm{D}_{200}$, which corresponded to 100,150 and $200 \mathrm{mg}$ of $\mathrm{N}$-sludge $\mathrm{kg}^{-1}$ soil $(\mathrm{n}=20)$, respectively. Thirty days after liming, period in which soil moisture was kept at $70 \%$ of the retention capacity, soil samples were taken and analyzed for total and extractable $\mathrm{Fe}, \mathrm{Cu}, \mathrm{Mn}, \mathrm{Zn}, \mathrm{Cd}, \mathrm{Pb}, \mathrm{Ni}$, and $\mathrm{Cr}$. The application of WTS increased heavy-metal contents in the degraded soil. Although heavy metals were below their respective critical limits, sludge application onto degraded areas may cause hazardous environmental impact and thus must be monitored. Key words: soil reclaim, tin mining, Mehlich 1, environmental pollution
\end{abstract}

\section{METAIS PESADOS EM SOLO DEGRADADO TRATADO COM LODO DE ESTAÇÃO DE TRATAMENTO DE ÁGUA}

\begin{abstract}
RESUMO: A aplicação do lodo de estação de tratamento de água (LETA) em solos degradados é uma alternativa tanto para disposição desse resíduo como para a recuperação do solo. Neste trabalho avaliaram-se os efeitos do LETA nos teores de metais pesados em um Latossolo degradado por mineração de cassiterita na Floresta Nacional do Jamari, RO, Brasil. Utilizou-se delineamento experimental inteiramente casualizado com cinco tratamentos: testemunha $(n=4)$; testemunha química, que recebeu apenas calagem $(n=4)$ e doses $D_{100}, D_{150}$ e $\mathrm{D}_{200}$ (respectivamente 100, 150 e $200 \mathrm{mg} \mathrm{de} \mathrm{N} \mathrm{kg}^{-1}$ solo na forma de LETA), aplicadas antes da calagem (n =20). Após 30 dias da calagem, período em que o solo contido nos vasos foi mantido com teor de umidade próximo à capacidade de retenção, coletaram-se amostras de solo, que foram analisadas com relação aos teores totais e extraíveis de $\mathrm{Fe}, \mathrm{Cu}, \mathrm{Mn}, \mathrm{Zn}, \mathrm{Cd}, \mathrm{Pb}$, Ni e Cr. A aplicação de LETA aumentou os teores dos metais pesados do solo. A aplicação deste tipo de lodo em áreas degradadas pode causar impacto ambiental e, portanto, deve ser monitorada.

Palavras-chave: recuperação de solo, mineração de estanho, Mehlich 1, poluição
\end{abstract}

\section{INTRODUCTION}

The water treatment sludge (WTS), indiscriminately returned to watercourse, causes alterations in the flora and the fauna (Cordeiro, 1999) because it contains sand, silt and clay, humic and mineral substances, chemical coagulants, heavy metals and, depending on the water source, pathogenic microorganisms. Minimizing the negative environmental effects of this residue is a great challenge. Alternatives for use of WTS are cement manufacturing, brick making, disposal in sanitary earthwork, composting (with yard waste or sewage sludge), soil potting, and soil disposal (agriculture, forest, soil reclaim) (AWWA, 1999, Morita et al., 2002).

The main advantage of the agricultural use of WTS is the improvement of the physical characteris- tics of soils resulting from large amounts of clay present in the residue (Skene et al., 1995). Application of WTS improves soil aggregation, raises $\mathrm{pH}$, supplies nutrients to plants, increases water retention capacity, and soil aeration. Therefore, in some parts of the world, WTS in already applied onto agricultural soil, as is the case of Atlanta and New Jersey in the USA (AWWA, 1999), and Portugal in the European Union.

Data on application of WTS to agricultural soils in Brazil is scarce, and demand research to define advantages and risks of this soil management practices. The objective of this study was to evaluate the effects of the application of WTS to a degraded soil from tin mining in the National Forest of Jamari, state of Rondonia, Brazil, on soil's heavy metals contents. 


\section{MATERIAL AND METHODS}

\section{Place, experimental design and treatments}

The study was developed in a greenhouse (25$28^{\circ} \mathrm{C}$ ) in Jaboticabal, SP, Brazil. Trials were set up in a completely randomized design, with five treatments: $\mathrm{T}=$ control, soil degraded $(n=4) ; T c=$ chemical control, soil degraded + liming $(\mathrm{n}=4) ; \mathrm{D}_{100}, \mathrm{D}_{150}$ and $\mathrm{D}_{200}=$ liming + 100,150 and $200 \mathrm{mg}$ of N-WTS for $\mathrm{kg}$ of soil $(\mathrm{n}=20)$.

\section{Characterization of the degraded soil and the WTS}

Before mining activity, the area's soil was classified as Typic Hapludox. Samples for the study were collected at the $0-20 \mathrm{~cm}$ layer, and presented the following physico-chemical properties: $\mathrm{pH}\left(0.01 \mathrm{~mol} \mathrm{~L}^{-1} \mathrm{CaCl}_{2}\right)=$ 4.9 ; organic matter $=3 \mathrm{~g} \mathrm{dm}^{-3} ; \mathrm{P}$ (resin extractor) $=8 \mathrm{mg}$ $\mathrm{dm}^{-3} ; \mathrm{K}=0.5 \mathrm{mmol}_{\mathrm{c}} \mathrm{dm}^{-3} ; \mathrm{Ca}=5.0 \mathrm{mmol}_{\mathrm{c}} \mathrm{dm}^{-3} ; \mathrm{Mg}=$ $2.0 \mathrm{mmol} \mathrm{dm}^{-3} ; \mathrm{H}+\mathrm{A} \mathrm{l}=12 \mathrm{mmol} \mathrm{dm}^{-3}$; sum of bases $=$ $7.5 \mathrm{mmol}_{\mathrm{c}} \mathrm{dm}^{-3}$; CEC $=19.5 \mathrm{mmol}_{\mathrm{c}} \mathrm{dm}^{-3}$ and bases saturation $=38 \%$. Chemical analysis were carried out according to Raij et al. (1996).

WTS samples were collected in the Water Treatment Plant of Araraquara (SP), which works under conventional treatment, using iron chloride as coagulant agent. A suction pump was installed at the end of the treatment unit, and was turned on during sludge discharge for ten consecutive days. The composite sample was conditioned in a 1000-L fiber container. Superficial water was discharged through a siphon in a daily basis, and when the residue reached circa $98 \%$ moisture, it was removed from the container, conditioned in plastic bags, taken to the experimental unit, and stored in 500-L fiber container. During 20 days, the container was kept open along the day, and the water layer was siphoned out to bring sludge moisture to about $94 \%$, when a sample for chemical and physical characterizations was taken. The physico-chemical properties of the prepared sludge was: moisture $=$ $98 \%$, organic- $\mathrm{C}=10.5 \mathrm{~g} \mathrm{~kg}^{-1}$, total- $\mathrm{N}=2.2 \mathrm{~g} \mathrm{~kg}^{-1}, \mathrm{P}=$ $1.3 \mathrm{~g} \mathrm{~kg}^{-1}, \mathrm{~K}=2.2 \mathrm{~g} \mathrm{~kg}^{-1}, \mathrm{Ca}=121 \mathrm{~g} \mathrm{~kg}^{-1}, \mathrm{Mg}=4.3 \mathrm{~g}$ $\mathrm{kg}^{-1}, \mathrm{~S}=4.1 \mathrm{~g} \mathrm{~kg}^{-1}, \mathrm{Fe}=167040 \mathrm{mg} \mathrm{kg}^{-1}, \mathrm{Zn}=65.6 \mathrm{mg}$ $\mathrm{kg}^{-1}, \mathrm{Cu}=149 \mathrm{mg} \mathrm{kg}^{-1}, \mathrm{Mn}=1683 \mathrm{mg} \mathrm{kg}^{-1}, \mathrm{~Pb}=8.4 \mathrm{mg}$ $\left.\mathrm{kg}^{-}\right), \mathrm{Cr}=86 \mathrm{mg} \mathrm{kg}^{-1}, \mathrm{Ni}=27 \mathrm{mg} \mathrm{kg}^{-1}, \mathrm{Cd}=6.1 \mathrm{mg} \mathrm{kg}^{-1}$, clay $=260 \mathrm{~g} \mathrm{~kg}^{-1}$ silt $=315 \mathrm{~g} \mathrm{~kg}^{-1}$, and sand $=425 \mathrm{~g} \mathrm{~kg}^{-1}$. Organic-C was determined by wet oxidation (Dabin, 1976); the total-N by the Kjeldahl method, and other elements by AAS in the extract of digestion with $\mathrm{HNO}_{3}$, $\mathrm{HCl}$ and $\mathrm{H}_{2} \mathrm{O}_{2}$ (USEPA, 1995). Granulometric analysis was carried out as recommended by EMBRAPA (1997).

\section{Experimental procedures}

Pots with $6 \mathrm{~kg}$ capacity were filled with $5 \mathrm{~kg}$ of degraded soil. Rates of the prepared WTS were applied to the soil surface daily during 15 days, according to the water retention capacity. After application of half doses of each treatment, the soil was removed from the pots, placed on trays, homogenized and then returned to the respective pot, and the other half of the WTS dose was applied. The soil was again removed from the pots, placed on trays, dried at room temperature, passed through a soil mill, homogenized and returned to the respective pots.

After the application of the WTS, soils of the Tc, $\mathrm{D}_{100}, \mathrm{D}_{150}, \mathrm{D}_{200}$ received 3.3; 3.6; 3.7 and $3.9 \mathrm{~g}$ dolomitic limestone (total relative neutralization power $=131 \%$ ), respectively, corresponding to a field application equivalent to $2 \mathrm{t} \mathrm{ha}^{-1}$ to raise bases saturation to circa $70 \%$. After liming, the pots were wetted with distilled water to reach circa $70 \%$ of water retention capacity, covered with paper, and incubated at greenhouse conditions for 30 days, period in which the water lost by evaporation was replaced every two days. After the incubation, soil was removed from these pots, placed on plastic trays, air dried and sieved to $2 \mathrm{~mm}$. A sample from each treatment was used for heavy metal analysis.

\section{Heavy metals analysis and $\mathbf{p H}$ determination}

Total contents of $\mathrm{Cu}, \mathrm{Fe}, \mathrm{Mn}$, and $\mathrm{Zn}$ were determined in the extract of the nitric-percloric digestion by AAS using air-acetylene flame; total contents of $\mathrm{Cd}, \mathrm{Pb}$, $\mathrm{Ni}$ and $\mathrm{Cr}$ were determined in the extract of the digestion with $\mathrm{HNO}_{3}, \mathrm{HCl}$ and $\mathrm{H}_{2} \mathrm{O}_{2}$ (USEPA, 1995) by AAS using air-acetylene flame $(\mathrm{Cd}, \mathrm{Pb}$ and $\mathrm{Ni})$ or nitrous acetylene-oxide $(\mathrm{Cr})$. Extractable micronutrients and heavy metals were determined by the Mehlich 1 extractor (Jones Jr., 1990) and analyzed by AAS as described; $\mathrm{pH}$ was measured in water, using the ratio $1: 2.5$ (soil:water).

\section{Data analysis}

Data were submitted to analysis of variance $(P=0.05)$ and, the Tukey test was used for comparison of means $(P=0.05)$ (Banzatto \& Kronka, 1992).

\section{RESULTS AND DISCUSSION}

\section{$\mathrm{Fe}, \mathrm{Cu}, \mathrm{Mn}, \mathrm{Zn}$ and Ni contents}

Total contents of $\mathrm{Fe}, \mathrm{Cu}$ and $\mathrm{Mn}$ increased with the application of WTS, effect that was not observed for the total contents of $\mathrm{Zn}$ (Table 1). The extractable contents of these micronutrients increased as a function of WTS doses. Total iron contents increased more than the other metals. Total Fe contents ranged between the ordinary limits found for Brazilian soils. For instance, a Typic Hapludox presents more than $36 \% \mathrm{Fe}_{2} \mathrm{O}_{3}$ (Embrapa, 1999).

The WTS presents large quantities of Fe in the soluble form (Elliot et al. 1990). There are two explanations for high content found for extractable $\mathrm{Fe}$ in this study. First, a effect of the coagulant used (iron chloride) in the water treatment sludge and second, the action of the Mehlich-1 extractor, that contains a mixture of two 
Table 1 - Total and extractable contents of heavy metals plant nutrients in a degraded soil by tin mining amended with water treatment sludge.

\begin{tabular}{|c|c|c|c|c|c|}
\hline Treatment & $\mathrm{Ni}$ & $\mathrm{Fe}$ & $\mathrm{Cu}$ & $\mathrm{Mn}$ & $\mathrm{Zn}$ \\
\hline \multicolumn{6}{|c|}{ Total Heavy Metals (mg kg-1 dry basis) } \\
\hline $\mathrm{T}$ & $4.68 \mathrm{a}$ & $61072 \mathrm{a}$ & $41.28 \mathrm{ab}$ & $198.63 \mathrm{a}$ & $79.63 \mathrm{a}$ \\
\hline $\mathrm{T}_{\mathrm{c}}$ & $4.85 \mathrm{a}$ & 59716 a & $37.98 \mathrm{a}$ & $199.50 \mathrm{a}$ & $89.75 \mathrm{a}$ \\
\hline $\mathrm{D}_{100}$ & $5.84 \mathrm{a}$ & 70277 a & $51.22 \mathrm{bc}$ & $371.23 \mathrm{~b}$ & $111.84 \mathrm{a}$ \\
\hline $\mathrm{D}_{150}$ & $5.66 \mathrm{a}$ & $76620 \mathrm{a}$ & $54.96 \mathrm{c}$ & $387.80 \mathrm{~b}$ & $93.72 \mathrm{a}$ \\
\hline $\mathrm{D}_{200}$ & $6.14 \mathrm{a}$ & $90277 \mathrm{~b}$ & $56.34 \mathrm{c}$ & $373.78 \mathrm{~b}$ & 88.22 a \\
\hline \multicolumn{6}{|c|}{ Extractable Heavy Metals (mg kg ${ }^{-1}$ dry basis) } \\
\hline $\mathrm{T}$ & $0.30 \mathrm{a}$ & $6.63 \mathrm{a}$ & $0.23 \mathrm{a}$ & $4.67 \mathrm{a}$ & $0.33 \mathrm{a}$ \\
\hline $\mathrm{T}_{\mathrm{c}}$ & $0.80 \mathrm{a}$ & $7.89 \mathrm{a}$ & $0.30 \mathrm{a}$ & $4.67 \mathrm{a}$ & $1.6 \mathrm{a}$ \\
\hline $\mathrm{D}_{100}$ & $0.72 \mathrm{~b}$ & $5801 \mathrm{~b}$ & $6.54 \mathrm{~b}$ & $59.58 \mathrm{~b}$ & $2.30 \mathrm{~b}$ \\
\hline $\mathrm{D}_{150}$ & $0.84 \mathrm{c}$ & $8254 \mathrm{c}$ & $7.87 \mathrm{c}$ & $71.26 \mathrm{c}$ & $3.06 \mathrm{c}$ \\
\hline $\mathrm{D}_{200}$ & $0.85 \mathrm{c}$ & $9695 \mathrm{~d}$ & $10.17 \mathrm{~d}$ & $90.40 \mathrm{~d}$ & $3.84 \mathrm{~d}$ \\
\hline
\end{tabular}

strong acids $\left(\mathrm{H}_{2} \mathrm{SO}_{4}\right.$ and $\left.\mathrm{HCl}\right)$ and may solubilize partialy insoluble forms of $\mathrm{Fe}$ in the soil (Simonete \& Kiehl, 2002), possibly not available to plants (Amaral Sobrinho et al., 1993). This last effect is enhanced when $\mathrm{pH}$ is above 6.6 (Camargo et al., 1982). In the control treatment, $\mathrm{pH}$ was small than 6.6 , which may have resulted in the low contents of Fe recorded. Moreover, the degraded soil probably had low contents of extractable Fe.

WTS application increased the total copper contents in the three tested doses; values lied within limits found by Fageria et al. (2002) for Brazilian soils. Oliveira \& Mattiazzo (2001) recorded an average $40 \mathrm{mg} \mathrm{kg}^{-1}$ total $\mathrm{Cu}$ in soils amended with sewage sludge. Comparing to values observed by Galvão (1999) to savannah soils treated with WTS, the contents of extractable $\mathrm{Cu}$ were very high. These extractable contents increased proportionally to the increment of WTS doses. WTS increased total and extractable contents of Mn, but only the extractable Mn increased proportionally to WTS doses (Table 1). For soils with $\mathrm{pH}$ (in water) above of 6.6 and treated with limestone Camargo et al. (1982) observed increasing contents of Mn when Mehlich-1 extractor was used. Those authors found values of extractable Mn varying from 87.4 to $120 \mathrm{mg} \mathrm{kg}^{-1}$, corroborating findings of this study, where extractable contents of Mn were $90 \mathrm{mg} \mathrm{kg}^{-1}$ in the higher WTS doses. The total contents of Zn ranged as expected for Brazilian soils (Muraoka et al., 1984) and differences among treatments were not detected. The extractable contents of Zn increased with the WTS doses, and values ranged as expected for soils of the state of São Paulo (Camargo et al., 1982), and for sandy soils treated with WTS (Elliot \& Singer, 1988).

Regarding Ni, the extractable contents increased with WTS application. The average contents were con- sidered low, probably because of the adsorption, so the risks to environmental impacts are low (McGrath, 1995). Practically all the Ni added to oxidic soils with $\mathrm{pH}$ next to 7.0 is adsorbed and, probably occurred an increase in the adsorption of $\mathrm{Ni}$ when the values of soil $\mathrm{pH}$ were above 7.0 (Mellis et al., 2004).

\section{$\mathrm{Cd}, \mathrm{Cr}$ and $\mathrm{Pb}$ contents}

Total $\mathrm{Cd}, \mathrm{Cr}$ and $\mathrm{Pb}$ contents recorded for treatments with WTS were below the limits established by USEPA (1995) and by the legislation of CETESB (1999) for the state of São Paulo (Table 2). Although no difference has been detected in the total contents of $\mathrm{Pb}$, the contents of $\mathrm{Cd}$ and $\mathrm{Cr}$ increased in some doses of WTS, but without a clear relation dose-effect. In regard to the extractable contents, treatments that received WTS always presented higher contents of those heavy metals. A negative relationship was observed between $\mathrm{Cd}$ contents and WTS doses, while Cr increased with increasing WTS doses. This effect was less clear regarding $\mathrm{Pb}$ therefore there was not a linear relation. Cd was the more extracted heavy metal by Mehlich 1 extractant, in comparison to the total contents (Table 2). Annual applications of WTS could cause phytotoxicity to cultivated plants, once $\mathrm{Cd}$ should be in high concentrations, even in a soil with alkaline reaction, as observed by Hinesly et al. (1984).

The extractable fractions of $\mathrm{Pb}$ and $\mathrm{Cr}$ were lower than $1 \%$ of the total. Probably, this low extraction is associated to the high value of $\mathrm{pH}$, as suggested by Davies (1995) and Elliot \& Singer (1988). As a matter of fact, $\mathrm{pH}$ value in the different treatments were $\mathrm{T}=5.5 ; \mathrm{Tc}=$ $6.1 ; \mathrm{D}_{100}=7.6 ; \mathrm{D}_{150}=7.8$ and $\mathrm{D}_{200}=7.9$, indicating that soils of the treatments that received WTS were alkaline. Despite of the potential benefits of WTS, applied to the 
Table 2 - Total and extractable contents of heavy metals plant nutrients in a soil degraded by tin mining amended with water treatment sludge.

\begin{tabular}{|c|c|c|c|}
\hline Treatment & $\mathrm{Cd}$ & $\mathrm{Cr}$ & $\mathrm{Pb}$ \\
\hline \multicolumn{4}{|c|}{ Total Heavy Metals (mg kg-1 dry basis) } \\
\hline $\mathrm{T}$ & $0.78 \mathrm{~b}$ & $40.15 \mathrm{ab}$ & $69.86 \mathrm{a}$ \\
\hline $\mathrm{T}_{\mathrm{c}}$ & $0.82 \mathrm{~b}$ & $46.65 \mathrm{ab}$ & $52.84 \mathrm{a}$ \\
\hline $\mathrm{D}_{100}$ & $0.98 \mathrm{c}$ & $51.76 \mathrm{~b}$ & $74.22 \mathrm{a}$ \\
\hline $\mathrm{D}_{150}$ & $0.65 \mathrm{ab}$ & $47.50 \mathrm{ab}$ & $72.38 \mathrm{a}$ \\
\hline $\mathrm{D}_{200}$ & 0.77 a & $41.34 \mathrm{a}$ & $75.49 \mathrm{a}$ \\
\hline \multicolumn{4}{|c|}{ Extractable Heavy Metals (mg kg ${ }^{-1}$ dry basis) } \\
\hline $\mathrm{T}$ & $0.07 \mathrm{a}$ & $0.08 \mathrm{a}$ & $1.47 \mathrm{a}$ \\
\hline $\mathrm{T}_{\mathrm{c}}$ & $0.08 \mathrm{a}$ & 0.08 a & $1.50 \mathrm{a}$ \\
\hline $\mathrm{D}_{100}$ & $0.55 \mathrm{~d}$ & $1.27 \mathrm{~b}$ & $2.49 \mathrm{c}$ \\
\hline $\mathrm{D}_{150}$ & $0.47 \mathrm{c}$ & $1.46 \mathrm{c}$ & $2.44 \mathrm{c}$ \\
\hline $\mathrm{D}_{200}$ & $0.40 \mathrm{~b}$ & $1.59 \mathrm{~d}$ & $2.20 \mathrm{~b}$ \\
\hline
\end{tabular}

$\mathrm{T}=$ control (degraded soil); $\mathrm{Tc}=$ chemical control $($ degraded soil + limestone); $\mathrm{D}_{100} . \mathrm{D}_{150}$ and $\mathrm{D}_{200=}=$ application of 100,150 and 200 mg of N-WTS kg-1 of degraded soil + limestone. Means followed by the same letter in the same column and same form of heavy metal are not different by Tuckey's test at $P<0.05$.

soil (increase in $\mathrm{pH}$, addition of nutrients and clay), negative effects have been found as adsorption of phosphorus and phytotoxicity with aluminum (AWWA, 1999). In the state of New Jersey (U.S.A.), 100\% of the residues of water treatment plants contain aluminum (AWWA, 1999). Moreover, Elliot et al. (1990) observed that, although WTS presents low metal contents, they are in a mobile form and present potential for environment contamination.

\section{REFERENCES}

AMARAL SOBRINHO, N.M.B.; COSTA, L.M.; DIAS, L.E.; BARROS, N.F. Aplicação de resíduo siderúrgico em um latossolo: Efeito na correção do solo e na disponibilidade de nutrientes e metais pesados. Revista Brasileira de Ciência do Solo, v.17, p.299-304, 1993.

AWWA. USEPA. Commercial application and marketing of water plant residuals. Denver: AWWA Research Foundation, 1999. 186p.

BANZATTO, D.A.; KRONKA, S.N. Experimentação agrícola. 2.ed. Jaboticabal: Funep, 1992. 247p.

CAMARGO, O.A.; VALADARES, J.M.A.S.; DECHEN, A.R. Efeitos do $\mathrm{pH}$ e da incubação na extração do manganês, zinco, cobre e ferro no solo. Revista Brasileira de Ciência do Solo, v.6, p.83-88, 1982.

COMPANHIA DE TECNOLOGIA DE SANEAMENTO AMBIENTAL CETESB. Aplicação de lodos de sistemas de tratamento biológico em áreas agrícolas. Critérios para projetos e operação. São Paulo: CETESB, 1999. 32p. (Manual Técnico, p.4230).

CORDEIRO, J.S. Importância do tratamento e disposição adequada dos lodos de ETAs. In: REALI, M.A.P. (Ed.) Noções gerais de tratamento e disposição final de lodos de estações de tratamento de água. Rio de Janeiro: ABES, 1999. p.1-18.
DABIN, B. Curso sobre matéria orgânica do solo. Parte 1. Análise dos compostos húmicos do solo. Piracicaba: CENA, 1976. 115p.

DAVIES, B.G. Lead. In: ALLOWAY, B.J. (Ed.) Heavy metals in soils. 2.ed. London: Blackie Academic \& Professional, 1995. p.206-223.

ELLIOT, H.A.; DEMPSEY, B.A.; MAILLE, P.J. Content and fractionation of heavy metals in water treatment sludges. Journal of Environmental Quality, v.19, p.330-334, 1990

ELLIOT, H.A.; SINGER, L.M. Effect of water treatment sludge on growth and elemental composition of tomato (Lycopersion esculentum) shoots. Communications in Soil Science and Plant Analysis, v.19, p.345-354, 1988.

EMPRESA BRASILEIRA DE PESQUISA AGROPECUÁRIA. Manual de métodos de análise de solo. 2.ed. Rio de Janeiro: EMBRAPA, CNPS, 1997.

EMPRESA BRASILEIRA DE PESQUISA AGROPECUÁRIA. Sistema brasileiro de classificação de solos. Rio de Janeiro: Embrapa: Solos, 1999. 412p.

FAGERIA, N.K.; BALIGAR, V.C.; CLARK, R.B. Micronutrients in crop production. Advances in Agronomy, v.77, p.185-265, 2002.

GALRÃO, E.Z. Métodos de aplicação de cobre e avaliação da disponibilidade para a soja num Latossolo Vermelho-Amarelo franco argilo-arenoso fase cerrado. Revista Brasileira de Ciência do Solo, v.23, p.265-272, 1999.

HINESLY, T.D.; ZIEGLER, E.L.; BARRET, G.L. Cadmium and zinc uptake by corn (Zea mays L.) with repeated applications of sewage sludge. Journal of Agricultural and Food Chemistry, v.32, p.155-163, 1984.

JONES JR., J.B. Universal soil extractants: their composition and use. Communications in Soil Science and Plant Analysis, v.21, p.10911101, 1990.

MELLIS, E.V., CRUZ, M.C.P., CASAGRANDE, J.C. Nickel adsorption by soils in relation to $\mathrm{pH}$, organic matter, and iron oxides. Scientia Agricola, v.61, p.190-195, 2004.

McGRATH, S.P. Chromium and nickel. In: ALLOWAY, B.J. (Ed.) Heavy metals in soils. 2.ed. London: Blackie Academic and Professional, 1995. p.152-174.

MORITA, D.M.; SAMPAIO, A.O.; MIKI, M.K.; DAVID, A.C. Incorporação de lodos de estações de tratamentos de água em blocos cerâmicos. (Compact disc) In: ENCONTRO NACIONAL DE SANEAMENTO BÁSICO; SIMPÓSIO LUSO-BRASILEIRO DE ENGENHARIA SANITÁRIA E AMBIENTAL, 10., Braga, 2002. Braga: ABES, 2002.

MURAOKA, T.; NEPTUNE, A.M.L.; NASCIMENTO FILHO, V.F. Avaliação da disponibilidade de zinco e manganês do solo para o feijoeiro. I Zinco. Revista Brasileira de Ciência do Solo, v.7, p.167176, 1984.

OLIVEIRA, F.C.; MATTIAZZO, M.E. Mobilidade de metais pesados em um Latossolo Amarelo Distrófico tratado com lodo de esgoto e cultivado com cana-de-açúcar. Scientia Agricola, v.58, p.807-812, 2001.

RAIJ, B. van.; CANTARELLA, H.; QUAGGIO, J.A.; FURLANI, A.M.C. Recomendações de adubação e calagem para o Estado de São Paulo. 2. ed. Campinas: Instituto Agronômico \& Fundação IAC, 1996. 285p.

SIMONETE, M.A.; KIEHL, J.C. Extração e fitodisponibilidade de metais em resposta à adição de lodo de esgoto no solo. Scientia Agricola, v.59, p.555-563, 2002.

SKENE, T.M.; OADES, J.M.; KILMORE, G. Water treatment sludge: a potential plant growth medium. Soil Use and Management, v.11, p.2933, 1995.

UNITED STATES ENVIRONMENTAL PROTECTION AGENCYUSEPA. A guide to the biosolids risks assessments for the EPA part 503 rule. Washington: USEPA, 1995. 143p. (EPA/832-B-93-005).

Received August 16, 2004

Accepted July 14, 2005 